\title{
Stock And Bond Price Dynamics-Evidence From An Emerging Economy
}

M.Venkateshwarlu, National Institute of Industrial Engineering (NITIE), India

T. Ramesh Babu, National Institute of Industrial Engineering (NITIE), India

\begin{abstract}
The motivation for this study is that real stock prices are observed to overreact to changes in interest rates. The real stock prices drop when long-term interest rates rise. It has been observed that bonds and stock prices are typically studied in isolation. The present paper attempts to analyze the dynamic linkages between stock and bond prices in India.

One of the important contributions of this study is that in India, very littlelalmost no work has been done to understand the dynamics of the stock and bond prices after the recent recession. The present study examined the bivariate causal relationship between stock prices and bond prices. In the long term; i.e., periods from 2004 to 2007 and 2008 to 2009, there is no causality from stock market to bond market and vice versa. However, it is found that the bond and stock prices had a bivariate causality in the year 2009 and univariate causality in 2010. The results are interesting and support the view that excess volatility causes granger between the stock and bond markets. This can be inferred as a result of recession investors moving to bond markets and after the signs of recovery the investors might be returning to the stock markets.

It is also evident that short-term interest rates have power to forecast short-term stock returns and risk premiums on observation of co-movement between stock and bond prices. This is reiterated by many empirical studies that have shown that the term "structure of nominal interest rates" contains information potentially useful for the conduct of monetary policy.
\end{abstract}

Keywords: Stock Prices; Bond Prices; Dynamic Linkages; India

\section{INTRODUCTION}

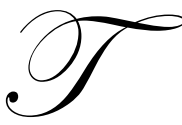

he real stock prices drop when long-term interest rates rise (and rise when they fall) Shiller and Beltratti (1992). It has been observed that bonds and stock prices are typically studied in isolation, and when they are studied together, stock and bond prices are considered only at the aggregate index level. Yet, there are non-exclusive reasons why stocks might differ in how they commove with bonds (Ehrammn, Fratzscher, and Rigobon, 2004).

Analyzing the movements of stock and bond prices is important for institutional and individual investors in managing their portfolios. Many investors use a tactical asset allocation strategy whereby the shift their investments between stocks and bonds in different anticipated capital market conditions. If the stock and bond prices are positively correlated and/or stock and bond markets are integrated, this tactical strategy is not a good strategy, in general. The key elements in portfolio constitution are estimates of return, risk and correlations of assets in a portfolio. The researchers primarily focused on estimating the returns and risk and have assumed that correlations are constant (Abdul Hakeem and Michael McAlear, 2009). When the investors are scared, they look for safety and adjust their portfolios to include more safe assets. This kind of movement is usually referred to as 'flight to quality'

The paper is organized in seven parts -introduction, review of literature, data and data sources, analysis of historical volatility, empirical methodology, empirical results, and conclusions and recommendations, including fture research. 


\section{REVIEW OF LITERATURE}

An extensive review of literature on the importance and relationship between stock and bond prices indicates that the researchers followed two different approaches:

1. Studies that examine the relationship between short-run stock returns and short-term interest rates (Fama and Schwartz, 1977; Campbell, 1987; and Ferson, 1989). These studies find that short-term interest rates have power to forecast short-term stock returns and risk premiums.

2. To use the term spread (difference between short-term and long-term interest rates) to forecast stock returns and/or risk premiums. The studies of Fama and French (1989) and Schwert (1990) focused on the second approach. Through the studies examining predictive power of term spreads to forecast short-term horizon stock returns with linear Vector Auto Regressions (VAR) approach, they found that real interest rates have very little impact on stock returns.

Another study to support this view is by Shiller and Beltraiti (1992) who examine the relationship between changes in stock prices and changes in long-term interest rates using simple, rational expectations present-value model and found that the relationship between changes in stock prices and bond yields is more negative than expected. We find clear evidence in the literature that the yield curve variables often used to predict stock returns on bonds, such as the term spread (Fama and French, 1998, and Shiller and Beltraiti, 1992) and combinations of forward rates (Cochrane and Piazzesi, 2005) also predict returns on bond-like stocks relative to more speculative stocks. Further in the other direction, the sentiment index that Baker and Wurgler (2006) use to predict the relative returns on bond-like and speculative stocks also has predictive power for bond returns.

The literature on financial linkages can be classified into two independent strands in recent years. One of the strands focuses on the domestic transmission of asset price shocks and its determinants. Another direction of the literature has been to analyze international linkages with a focus mostly on individual asset prices in isolation, usually equity markets or foreign exchange markets. This indicates that a gap in the existing research on linkages among multi-asset class and cross-country analysis is an area for researchers to focus.

Linkages across domestic financial markets are increasingly well researched and understood. The earlier works on the spillovers across different domestic asset prices often find a positive correlation between stock returns and bond yields, such as Shiller and Beltratti (1992) and, to some extent, Barsky (1989) and Campbell and Ammer (1993).

It is interesting to note that in the findings of Bernanke and Kuttner (2005) and Ehrmann and Fratzscher (2005), the equity prices react strongly to monetary policy shocks in the United States. At the same time, monetary policy has been shown to respond to equity markets (Rigobon and Sack, 2003). This indicates the interaction between monetary policy and stock prices. In a simultaneous analysis of bond prices, short-term interest rates and equity markets, Rigobon and Sack (2003) find that the causality of the transmission process may run in several directions; for instance, the correlation between US short-term interest rates and equity prices may change from positive to negative, depending on which of the asset prices is dominant in particular periods.

A review of closely related literature on asset price discovery focuses on explaining the price discovery process in domestic markets through economic fundamentals. Several papers concentrate on the importance of announcements and news of selected macroeconomic variables. Some of the important studies are Fleming and Remolona (1997, 1999), Balduzzi, Elton and Green (2001), and Bollerslev, Cai and Song (2000). This shows that macroeconomic news in the US is an important driving force behind US bond markets. In another study, Fleming and Remolona (1999) find a hump-shaped effect of macroeconomic news along the yield curve in that the largest effect of such news usually occurs at intermediate maturities.

For equity markets, Flannery and Protopapadakis (2002) and Boyd, Jagannathan and Hu (2005) also revealed a strong response of US equity markets to macroeconomic news, while the latter paper, as well as David and Veronesi (2004), show that the relationship between economic fundamentals and equity returns may, in some cases, be dependent on economic conditions or the type of news. 
There have also been various attempts to analyze international spillovers, though the focus in this literature has so far concentrated only on individual asset prices in isolation, mostly on equity markets. For instance, the empirical work by Hamao, Masulis and Ng (1990), King, Sentana and Wadhwani (1994), and Lin, Engle and Ito (1994), based on reduced-form GARCH models, detects some spillovers from the US to the Japanese and UK equity markets, both for returns and, in particular, for conditional volatility. Becker, Finnerty and Friedman (1995) also find spillovers between the US and UK stock markets and show that this is, in part, due to US news and information, although more recent work by Connolly and Wang (2003) argues that such macroeconomic news can explain only a small share of the equity market spillovers between mature economies. Regarding the foreign exchange markets, the seminal paper by Lin, Engle and Ito (1994) found strong spillovers in foreign exchange markets, both in conditional first and second moments. Finally, a related paper studying contagion across different countries and financial markets is Dungey and Martin (2004). They study mainly the transmission of volatility between short interest rate markets and stock markets across countries.

Recently Ramesh and Venkateshwarlu (2010) studied the co-integration of an emerging stock market (India) with the global stock markets. The study finds evidence of international integration of India's stock market in terms of stock prices measured in their local currencies. The studies on the effects of macroeconomic announcements on various asset prices, such as Andersen, Bollerslev, Diebold and Vega (2003) and Ehrmann and Fratzscher (2004), show that, in particular, US macroeconomic news has a significant effect on the US dollar-euro exchange rate. For bond markets, Goldberg and Leonard (2003) and Ehrmann and Fratzscher (2004) find that not only macroeconomic news is an important driving force behind changes in bond yields, but that there are significant international bond market linkages between the United States and the euro area.

The results of Ehrmann and Fratzscher (2004) indicate that spillovers are stronger from the US to the euro area market, but that spillovers in the opposite direction are present since the introduction of the euro in 1999. Finally, Andersen, Bollerslev, Diebold and Vega (2005), Fair (2003), and Faust, Rogers, Wang and Wright (2003) look at the effect of macro announcements on high-frequency asset returns across several asset prices, such as exchange rates and the yield curve, confirming the importance of news and, in some cases, finding a significant response of risk premia or an overshooting of exchange rates in the short run.

Another strand on international financial co-movements attempts to explain the evolution of financial spillovers through real and financial linkages of the underlying economies. Heston and Rouwenhorst (1994), Griffin and Karolyi (1998), and Brooks and Del Negro (2002) argue that mainly country-specific shocks, and, to a lesser extent, industry specific and global shocks, can explain international equity returns. In addition, several papers emphasize the importance of linkages through trade and capital flows for explaining financial market spillovers. One direction of the literature has been to focus on contagion in international markets, marked by the seminal work by Bae, Karolyi and Stulz (2003) and Forbes and Rigobon (2002). Hartmann, Straetmans and de Vries (2003) show that exchange rate linkages strengthen during financial crises for a broad set of emerging markets. Eichengreen and Rose (1999) and Glick and Rose (1999) find that the degree of bilateral trade, rather than country-specific fundamentals alone, play an important role for understanding financial co-movements during crisis episodes. Focusing on mature economies, Forbes and Chinn (2004) find that the country-specific factors have become somewhat less important and bilateral trade and financial linkages significantly are nowadays more important factors for explaining international spillovers across equity and bond markets.

A key characteristic of this literature on financial transmission is that it has evolved along distinct paths, one focusing exclusively on domestic cross-market linkages and others on the international transmission within individual asset markets. Few systematic attempts have been made to link these strands in order to gain a better understanding of the underlying nature of the transmission channels of financial shocks. The objective of this paper is to test the dynamic linkages between stock prices and bond prices prior to recession, during the recession, and after recovering from the recession.

\section{DATA AND DATA SOURCES}

The study uses daily closing values of popular stock market index viz, S\&P CNX NIFTY, and 90-day Tbill index of India is considered for examining the causality between bond prices and stock prices. The log returns 
are considered for the analysis of the data. The S\&P CNX NIFTY consists of 50 underlying stocks. The study period indicated in tables is calendar periods. The period of study is from January 1, 2004, to December 31, 2010. There are no data gaps or abnormalities during the study period. The period of study is after introduction of interest rate deregulation in 1993 and current account full convertibility in Indian foreign exchange market. Therefore, this can be expected to have significant implications for relationship between bond prices and stock prices. The data is drawn from two sources; i.e., NSE India Limited and Clearing Corporation of India Limited (CCIL).

\section{ANALYSIS OF HISTORICAL VOLATILITY}

With a view to understand the effect of volatility on the behavior of stock prices, the standard deviation has been computed for both bond and stock markets.

Table 1: Volatilities of Bond and Stock Markets

\begin{tabular}{|c|c|c|}
\hline & Bond & Stock \\
\hline Year & Std. Deviation & Std. Deviation \\
\hline 2004 & 1.13 & 175.27 \\
\hline 2005 & 2.08 & 251.52 \\
\hline 2006 & 1.48 & 321.74 \\
\hline 2007 & 1.43 & 542.36 \\
\hline 2008 & 1.12 & 825.52 \\
\hline 2009 & 1.03 & 305.59 \\
\hline
\end{tabular}

From Table 1, it is observed that the standard deviation of the stock index has been increasing from 145.27 to 825.52 (in absolute values) from year 2004 to 2009, respectively. Particularly during the years 2008-2009 and 2009-2010, the volatility has changed significantly - about 52\% (542.36 to 825.52) and 63\% (825.52 to 305.59), respectively. The standard deviation of the bond market has changed about $30 \%$ in $2009-2010$. These statistics will be useful in analyzing the results of causality between stock and bond prices in subsequent parts of the paper.

\section{METHODOLOGY}

This paper attempts to determine the relationship between the bond and stock markets. The time series technique involves three main steps: 1) testing the relevant time series for stationary (unit roots), 2) co-integration, and 3) testing for causality.

Primarily, the Granger causality is tested between the respective time series and the Granger test is primarily based on the following regressions:

$$
\begin{aligned}
& y_{t}=\alpha_{0}+\alpha_{1} y_{t-1}+\ldots+\alpha_{l} y_{t-l}+\beta_{1} x_{t-1}+\ldots+\beta_{l} x_{-l}+\epsilon_{t} \\
& x_{t}=\alpha_{0}+\alpha_{1} x_{t-1}+\ldots+\alpha_{l} x_{t-l}+\beta_{1} y_{t-1}+\ldots+\beta_{l} y_{-l}+u_{t}
\end{aligned}
$$

The null hypothesis is that $\mathrm{x}$ does not Granger-cause $\mathrm{y}$ in the first regression and y does not Granger-cause $\mathrm{x}$ in the second one.

Before application of Granger causality tests, it is necessary to test the series for stationarity, and if the series turn out to be non-stationary, then it is necessary that the two series must co-integrate. The stationarity is tested by using the Advanced Dicky Fuller test.

The implication of non-stationarity can lead to spurious regression when testing for Granger causality, unless a co-integrating vector is present. This makes the testing for co-integration mandatory (Shridhar K Dash, 2000). If such a stationary linear combination exists, the non-stationary time series is said to be co-integrated. The 
stationary linear combination is called the co-integrating equation and may be interpreted as a long-run equilibrium relationship among the variables. The test employed for determination of co-integration between the time series is Johnson's test. We could have employed the Engle-Granger (EG) procedure, as well as this is not a multivariate case, but the same effect can be produced by the Johnson's test.

A non-stationary time series $\mathrm{Yt}$ is said to be integrated of order $\mathrm{d},[\mathrm{Yt} \sim \mathrm{I}(\mathrm{d})]$ if it achieves stationarity after being differenced $d$ times ${ }^{1}$. To determine the order of integration, unit root tests have been developed. The most common test is known as Dickey-Fuller ${ }^{2}$ (DF) or Augmented Dickey-Fuller (ADF) ${ }^{3}$. To discuss the DF test, consider the model:

$\mathrm{Yt}=\beta 0+\beta 1 \mathrm{t}+\mathrm{ut}$

ut $=$ aut $-1+\varepsilon t$

where $\varepsilon t$ is a co-variance stationary process with zero mean. The reduced form for this model is

$\mathrm{Yt}=\gamma+\delta \mathrm{t}+\beta 1 \mathrm{t}+\alpha \mathrm{Yt}-1+\varepsilon \mathrm{t}$

where $\gamma=\beta 0(1-\alpha)+\beta 1 \alpha$ and $\delta=\beta 1(1-\alpha)$. This equation is said to have a unit root if $\alpha=1$. The DF test is based on testing the hypothesis $\alpha=1$ in (1) under the assumption that $\varepsilon t$ are white noise errors. The test statistics are:

$\mathrm{k}(1)=\mathrm{T}(\dot{\alpha}-1) \quad \mathrm{t}(1)=(\dot{\alpha}-1) / \mathrm{SE}(\dot{\alpha})$

Since these statistics do not have a standard $\mathrm{t}$ distribution, the critical values for $\mathrm{k}(1)$ and $\mathrm{t}(1)$ are tabulated in Fuller (1976).

Suppose that $\mathrm{Yt} \sim \mathrm{I}(\mathrm{d})$ and $\mathrm{Xt} \sim \mathrm{I}(\mathrm{d})$. Then $\mathrm{Yt}$ and $\mathrm{Xt}$ are said to be co-integrated if there exists a $\beta$, such that $Y t-\beta X t$ is $I(d-b)$ and $b>0$. Thus, testing for co-integration ${ }^{4}$ one must make sure that both series are integrated of the same order in the first step. The second step then involves estimating the following co-integration equation by Ordinary Least Squares (OLS):

$\mathrm{Yt}=\mathrm{a} 0+\mathrm{boXt}+\mu \mathrm{t}$

$\mathrm{Xt}=\mathrm{a} 0+$ bo $\mathrm{Yt}+\mu^{\prime} \mathrm{t}$

and testing for the stationarity of the residuals from Equations $2 \& 3$ makes sure that $\mu \mathrm{t}$ and $\mu^{\prime} \mathrm{t}$ are $\mathrm{I}(\mathrm{d}-\mathrm{b}), \mathrm{b}>0$.

If two variables are co-integrated, then the third step involves formulating the error-correction model (ECM) as follows:

$$
\begin{aligned}
& (1-L) Y_{t}=C_{0}+d_{0} \mu_{t-1}+\sum_{i=1}^{n} e_{o i}(1-L) Y_{t-i}+\sum_{i=1}^{n} f_{o i}(1-L) X_{t-i}+\varepsilon_{t} \\
& (1-L) X_{t}=C_{1}+d_{1} \mu_{t-1}^{\prime}+\sum_{i=1}^{n} e_{1 i}(1-L) X_{t-i}+\sum_{i=1}^{n} f_{1 i}(1-L) Y_{t-i}+\varepsilon_{t}^{\prime}
\end{aligned}
$$

where $\mathrm{L}$ is the lag operator and the error correction terms (ECTs), $\mu_{t}$ and $\mu_{t}^{\prime}$, are the stationary residuals from cointegration Equations 2 and 3, respectively. According to the standard Granger causality test, $\mathrm{X}$ is said to Granger cause $\mathrm{Y}$ if $\mathrm{f}_{\mathrm{oi}}$ 's are jointly significant. The inclusion of ECTs, however, provide additional channels through which

\footnotetext{
${ }^{1}$ This definition is due to Granger (1986) and Engle and Granger (1987).

${ }^{2}$ Dickey and Fuller (1979).

${ }^{3}$ Engle and Granger (1987) has argued that ADF test allows for dynamics in the DF regression and consequently is overparameterised in the first order case but correctly specified in the higher order cases.

${ }^{4}$ An alternate approach to test for co-integration is developed by Johansen $(1988,1991)$. Johansen method is more appropriate for models with more than two time series.
} 
the Granger causality could be detected. Thus, $\mathrm{X}$ is said to Granger cause $\mathrm{Y}$, as long as the ECT carries a significant coefficient, even if $\mathrm{f}_{\mathrm{oi}}$ 's are not jointly significant. ${ }^{5}$

\section{EMPIRICAL ESTIMATION AND ANALYSIS}

\section{Unit Root Test}

In order to obtain credible and robust results for any conventional regression analysis, the data to be analyzed should be stationary; therefore, it is necessary to examine if the series are stationary or not. Table 2 presents the results of an Augmented Dickey Fuller test which is performed to test unit root property for all the time series. ADF test was employed on a two-time series; namely, Bond Index and Stock Index NIFTY, and the respective results are presented in Table 2. The ADF test critical values are given below the table. From the critical values, it is understood that both the series viz, Bond Index and Stock Index NIFTY are found to be non-stationary at the levels and stationary for first difference during all the periods of the study.

Table 2: ADF Test Results: Indicators for Stationary

\begin{tabular}{|c|c|c|c|c|}
\hline Year & \multicolumn{2}{|c|}{ Level } & \multicolumn{2}{c|}{$\mathbf{1}^{\text {st }}$ Difference } \\
\hline & Bond & Stock & Bond & -13.53 \\
\hline 2004 & -2.55 & -0.71 & -13.42 & -14.22 \\
\hline 2005 & 3.73 & 0.65 & -17.15 & -15.34 \\
\hline 2006 & -1.13 & -1.03 & -21.56 & -14.99 \\
\hline 2007 & -2.42 & 0.31 & -21.03 & -15.63 \\
\hline 2008 & -0.53 & -1.42 & -14.82 & -16.04 \\
\hline 2009 & -0.82 & -0.68 & -18.13 & -14.75 \\
\hline 2010 & 0.562 & 0.40 & -15.22 & \\
\hline
\end{tabular}

\begin{tabular}{|l|c|c|}
\hline Test critical values: & $1 \%$ level & -3.46 \\
\hline & $5 \%$ level & -2.87 \\
\hline & $10 \%$ level & -2.57 \\
\hline
\end{tabular}

\section{Co-integration Analysis}

Co-integration analysis is performed for all the I(1) series. The results of co-integration analysis are presented in Table 3. The results indicate that we fail to reject the null hypothesis that no co-integration exists between either stock indices or the bond index as shown in Table 3. The integration results tell that the two markets (stock and bond) are co-integrated during all the periods considered for the study.

The implication of non-stationarity can lead to spurious regression when testing for granger causality unless a co-integrating vector is present. This makes the testing for co-integration mandatory. If such a stationary linear combination exists, the non-stationary time series is said to be co-integrated (Shridhar K Dash, 2000). To understand better about the relationship between stock and bond markest, we have to proceed to the causality analysis.

Table 3: Co- integration Results - Stock and Bond

\begin{tabular}{|c|c|c|c|c|c|}
\hline $\begin{array}{c}\text { Stock and Bond } \\
\text { Year }\end{array}$ & Trace & Critical values & Max. Eigen & $\begin{array}{c}\text { Critical } \\
\text { values }\end{array}$ & Result \\
\hline 2004 & 86.35 & 285.14 & 47.31 & 70.54 & Positive Co-integration \\
\hline 2005 & 70.94 & 285.14 & 44.68 & 70.54 & Positive Co-integration \\
\hline 2006 & 69.87 & 285.14 & 39.35 & 70.54 & Positive Co-integration \\
\hline 2007 & 70.24 & 285.14 & 43.89 & 70.54 & Positive Co-integration \\
\hline 2008 & 68.94 & 239.24 & 37.71 & 58.43 & Positive Co-integration \\
\hline 2009 & 74.87 & 285.14 & 45.54 & 58.43 & Positive Co-integration \\
\hline 2010 & 67.97 & 285.14 & 34.34 & 58.43 & Positive Co-integration \\
\hline
\end{tabular}

${ }^{5}$ Granger (1988), p. 203

98

(C) 2011 The Clute Institute 


\section{Granger Causality Test}

The F-statistics and probabilities from the granger causality test are presented in Table 4. Two regression analyses are done, from Stock Index NIFTY to Bond Index and Bond Index to Stock Index NIFTY - reverse causality testing. The lag length is selected as four. This is based on the fact that the better causality is predicted if we consider more than three previous observations. As mentioned is the introduction, the aim of the present paper is to study the causal relationship between the two markets (stock and bond) with different time periods. Therefore, the present causality analysis has been divided into two phases - first phase is testing the causal relation with long time periods and second phase is to test the causality with yearly time periods

\section{Analysis of Causality in the Long Term}

As discussed above, the study period is divided into two long-term periods - from 2004 to 2007 as one time period and 2008 to 2009 as one long-term period of study. In addition, we also analyzed the causality during 2010. The analysis indicates that during the periods 2004 to 2007 and 2008 to 2009, stock prices do not granger bond prices. Similarly, bond prices also do not granger cause stock prices during these periods. Surprisingly, during the year 2010, it is found that bond prices granger stock prices and stock prices do not granger bond prices.

Table 4: Causality Results Stock-Bond (Long-Term)

\begin{tabular}{|c|c|c|c|}
\hline Stock vs Bond vs Stock & F-Stat & Prob & Result \\
\hline $2004-2007$ & 0.58 & 0.67 & Stock does not Granger cause Bond \\
\hline & 1.09 & 0.35 & Bond does not Granger cause Stock \\
\hline $2008-2009$ & 0.17 & 0.95 & Stock does not Granger cause Bond \\
\hline 2010 & 1.98 & 0.09 & Bond does not Granger cause Stock \\
\hline & 1.02 & 0.39 & Stock does not Granger cause Bond \\
\hline
\end{tabular}

\section{Analysis of Causality in the Short Term}

With a view to track the causality in shorter intervals, we used calendar year data for analysis in shorter intervals. The results are shown in Table 5. In the short term, there has been a noticeable and statically significant causality from stock markets to bond markets during the years 2004, 2005 and 2009. Similarly, the causality from bond market to stock market is found in the year 2009 and 2010. As per the results shown in the Table 5, no causality was found in either direction during the years 2006, 2007 and 2008.

It is observed that there is a significant causality during 2004, 2009 to 2010 because of the volatility in the stock markets, which is concluded from the analysis of historical volatility (Table 1). The Standard Deviation values during the years 2008-2009 and 2009-2010 recorded about 52\% (542.36 to 825.52) and 63\% (825.52 to 305.59), respectively. During these years viz 2009 and 2010 only, we found the causality between these markets. We have also observed from Table 5 that the two markets (stock and bond) are bi-causal during this period.

Table 5: Causality Results Stock-Bond (Short-Term)

\begin{tabular}{|c|c|c|l|}
\hline Stock vs Bond & F-Stat & Prob & Result \\
\hline 2004 & 2.34 & 0.05 & Stock Granger cause Bond \\
\hline & 1.96 & 0.09 & Bond does not Granger cause Stock \\
\hline 2005 & 2.34 & 0.05 & Stock Granger cause Bond \\
\hline & 1.93 & 0.10 & Bond does not Granger cause Stock \\
\hline 2006 & 0.85 & 0.49 & Stock does not Granger cause Bond \\
\hline & 1.65 & 0.16 & Bond does not Granger cause Stock \\
\hline 2007 & 1.74 & 0.14 & Stock does not Granger cause Bond \\
\hline & 1.00 & 0.40 & Bond does not Granger cause Stock \\
\hline 2008 & 0.67 & 0.61 & Stock does not Granger cause Bond \\
\hline & 1.62 & 0.17 & Bond does not Granger cause Stock \\
\hline 2009 & 3.01 & 0.02 & Stock Granger cause Bond \\
\hline 2010 & 4.34 & 0.00 & Bond Granger cause Stock \\
\hline & 1.02 & 0.39 & Stock does not Granger cause Bond \\
\hline
\end{tabular}




\section{CONCLUSIONS - RECOMMENDATIONS}

In view of integration of financial markets, financial sector reforms, deregulation of interest rates and liberalization of capital accounts, it is important to analyze the dynamics between stock prices and bond prices. This is primarily due to the reason that during the times of excess volatility in the stock market, the investors move to bond markets to protect their portfolios, minimizing of risk and losses. The recent financial crisis emphasizes the need for understanding the changes in stock prices and their impact on bond prices and vice versa.

Theoretical frame work indicates that bond prices, to some extent, are influenced by the interest rates which are, in turn, dependent on monetary policy and other policy changes by the central bank. Hence, it is important to analyze the co movement between bond prices and stock prices to understand the likely impact of monetary policy and credit policy on the bond prices and also its impact on stock prices.

One of the important contributions of this study is that in India, very little/almost no work has been done to understand the dynamics of the stock and bond prices. The reason could be that Indian bond markets are primarily limited to the institutional investors, lack of automated trading systems, and government control until the early 2000s. In the long term; i.e., periods from 2004 to 2007 and 2008 to 2009, there is no causality from the stock market to the bond market and vice versa. However, it is found that the bond and stock prices had a bivariate causality in the year 2009 and univariate causality in 2010. The results are interesting and support the view that excess volatility causes granger between the stock and bond markets. This can be inferred that as a result of a recession, investors move to bond markets and after signs of recovery, they might return to the stock markets.

The results of this paper are similar to the findings of studies by Fama and Schwartz (1977), Campbell (1987), and Ferson (1989) which concluded that short-term interest rates have power to forecast short-term stock returns and risk premiums on observation of comment between stock and bond prices. This is reiterated by many empirical studies that have shown that the term "structure of nominal interest rates" contains information potentially useful for the conduct of monetary policy. For example, the studies by Mishkin (1990) and Jorion and Mishkin (1991) show that, in a number of countries, the spread between long and short-term nominal interest rates is a useful predictor of domestic price inflation.

Also embedded in a country's term "structure of interest rates" is information concerning future economic activity, as mentioned by Estrella and Mishkin (1996) and Bernard and Gerlach (1996) for many countries, that the long/short spread is a useful indicator of the likelihood of a future recession.

In conclusion, our analysis has indicated a close association between stock and bond markets in recent years, which has implications for regulators while formulating monetary and credit policies. Our analysis also casts doubts on the use of monetary policy for regulation of interest rates indirectly through monetary policy for the purpose of controlling inflation, exchange rate stability and liquidity in the market.

The results are useful for regulators, market participants and academicians. The results imply the market inefficiency and lend support to the technical analysis. The market participants may consider the relationship between the bond prices and stock index to predict the future movement of stock and bond prices effectively. Moreover, the results can help the regulators to understand the structure of the market in a better way and then design the policy. In terms of policy relevance, the regulators in India should be very careful in conducting monetary policies or capital market polices as it may impact on development of the financial markets.

Future research can be done by examining the co-integration between bond and stock markets by covering developed and other emerging markets. Moreover, the origin of nonlinearities in the variables can also be explored. Another interesting extension of this work would be to develop a forecasting model using the information of the bond index and stock market index. 


\section{AUTHOR INFORMATION}

Mr. T Ramesh Babu completed his masters in engineering from Indian Institute Technology, India, in 2008. He worked in the area of mathematical modelling of non-linear dynamic systems at IIT Madras. He then joined General Electric as an engineering analyst. He then joined CENDAC Labs in Pennsylvania, USA, where he was closely associated in developing mathematical models for non-linear and/or complex systems which are encountered in engineering and economics. He is now doing his research in the department of finance and economics at NITIE. His broad areas of interest include Quantitative Finance and Risk Management. He has 13 research articles in the areas of applied mathematics and finance.

M. Venkateshwarlu, Ph.D (Finance), holds a Ph.D in Corporate Finance. Dr. M. Venkateshwarlu has been working as an Associate Professor of Finance at NITIE, India. He has 20 years of teaching, training, consultancy and research experience in India and abroad. He was also a visiting faculty to IIM Bangalore, SJ School of Management, IIT Bombay. NISM, India. He has published 15 research articles on the themes of Valuation, Financial Economics and Capital Market Studies in journals of international repute and has also successfully conducted several consultancy projects for various leading corporations in India. E-mail: venkat@nitie.edu

\section{REFERENCES}

1. Abdul Hakeem and Micheal McAlear "Dynamic Condition in International Stock, Bond and Foreign Exchnage Markets - Emerging Markets Evidence" CIRJE -F 677, Faculty of Economics, (2009), University of Tokyo.

2. Andersen, T., Bollerslev, T., Diebold, F. X. and Vega, C., "Real - Time Price Discovery in Stock, Bond and Foreign Exchange Markets," Manuscript, (2005), Northwestern University, Duke University, University of Pennsylvania and University of Rochester.

3. Andersen, T., Bollerslev, T., Diebold, F. X. and Vega, P., "Modeling and Forecasting Realized Volatility," Econometrica, (2003), 71, 529-626

4. Bae, K. H., Karolyi, A. and Stulz, R., “A New Approach to Measuring Financial Contagion” Review of Financial Studies, (2003), 16, 717-763.

5. Baker, M., and Wurglar, J., "Investor Sentiment and Cross Section of Stock Returns" Journal of Finance, (2006), 61 (4) $1645-1680$.

6. Balduzzi, P., Elton, E. J. and Green, T. C., "Economic News and the Yield Curve: Evidence from the U.S. Treasury Market", Journal of Finance and Quantitative Analysis, (2001), 36,523-543.

7. Barsky, R. B., "Why don't the prices of stocks and bonds move together? American Economic Review, (1989), 79, $1132-1145$.

8. Becker, K. G., Finnerty, J. E. and Friedman, J., "Economic News and Equity Market Linkages between the U.S. and U.K.", Journal of Banking and Finance, (1995), 19, 1191-1210.

9. Bernanke, B. S. and Kuttner, K. N., "What Explains the Stock Market's Reaction to Federal Reserve Policy," Journal of Finance, (2004), 67(1), 259-262.

10. Bernard, H. and Gerlach, S., "Does The Term Structure Predicts recessions?- International Evidence", BIS Working Paper, (1996), Bank for International Settlement.

11. Bollerslev, T., Cai, J. and Song, F.M., "Intraday Periodicity, Long Memory Volatility, and Macroeconomic Announcement Effects in the U.S. Treasury Bond Market", Journal of Empirical Finance, (2000), 7, 37-55.

12. Boyd, J.H., Hu, J. and Jagannathan, R., "The Stock Market Reaction to Unemployment News: Why Bad News Is Usually Good for Stocks", Journal of Finance (2005), 60, 649-672.

13. Brooks, R., and Marco del Negro, "International Diversification Strategies." Working Paper, 2002-23, Federal Reserve Bank of Atlanta.

14. Campbell, J.Y. and John Ammer, "What moves the stock and bond market? Variance decomposition for long - term asset returns, Journal of Finance, (1993), 48, 3 - 37.

15. Campbell, J.Y. and Shiller, J., "Co-integration and Tests of Present Value Models". Journal of political Economy, (1987), 95, 1062-1088.

16. Campbell, J.Y., "Stock returns and the term structure," Journal of Finance Economics, (1987), 18, 373 399. 
17. Campbell, John Y. and Robert J. Shiller, Yield spreads and interest rate movements: A bird's eye view, Review of Economic Studies (1991) 58, 495 - 514.

18. Cochrane, J. and Monika, P., "Bond risk premia," American Economic Review (2005), 95, 138 - 160.

19. Connolly, R. and Wang, A. F., "International Equity Market Comovements: Economic Fundamentals or Contagion?", Pacific-Basin Finance Journal, (2003), 11, 23-43.

20. David, A. And Veronesi, P., "Inflation and Earnings Uncertainty and volatility Forecasts," Working paper, (2004), Washington University in St. Louis and University of Chicago.

21. Dickey, D. A. and Fuller, W.A., " Distribution of the Estimators for Autoregressive Time Series with a Unit Root," Journal of the American Statistical Association, (1979), 84, 427-31

22. Dungey M, Fry, R. and Martin, V.L., "Currency Market Contagion in the Asia a Pacific Region", Australian Economic Papers, (2004), 43, 379-395.

23. Ehramm and Fratzsher, "Taking stock Monitory Policy Transmission to Equity Market" Journal of Money, Credit and Banks, (2004), 36(4), 719 - 737.

24. Ehramm and Fratzsher, "Exchange Rates and Fundamentals New Evidence from Real Time Data", Journal of international Money and finance, (2005), 24(2) 317 - 341.

25. Ehramm, Fratzscher and Rigobon, “An International Financial Transmission Model”, European Central Bank, (2004), Frankfurt Germany.

26. Eichengreen, Barry and Andrew Rose "Contagious Currency Crises: Channels of Conveyance." In Takatoshi Ito and Anne Krueger, eds., Changes in Exchange Rates in Rapidly Developing Countries: Theory, Practice, and Policy Issues. Chicago: University of Chicago Press, (1999), 29-50.

27. Engle, R. F. and Granger, C.W.J., "Co-integration and Error Correction: Representation, Estimation, and Testing," Econometrica, (1987), 55, 251-76

28. Engle, R.F., "Dynamic Conditional Correlation: A Simple Class of Multivariate Generalized Autoregressive Conditional Heteroskedasticity Models," Journal of Business and Economic Statistics, (2002), 20, 339-350.

29. Estrella, A, and Mishkin, "Predicting US Recessions: Financial Variables as leading Indicators" Research Paper, 9609, (1996), Federal Reserve Bank of New York.

30. Fair, R., "Shock Effects on Stocks, Bonds and Exchange Rates", Journal of International Money and Finance, (2003), 22, 307-341.

31. Fama, E. and French, K. R., "Permanent and Temporary Components of Stock Price", Journal of Political Economy, (1998), 96, 246 - 273.

32. Fama, E. and French, K.R., "Business conditions and expected returns on bond and stocks, Journal of Finance Economics, (1989), 25, 23 - 49.

33. Fama, E. and Schwert, G.W., "Asset returns and inflation," Journal of Financial Economics, (1977), 5, 115 $-146$.

34. Faust, J., Rogers, J., Wang, S. and Wright, J., "The High Frequency Response of Exchange Rates and Interest Rates to Macroeconomic Announcements", Mimeo, (2003).

35. Ferson, W. E., "Changes in Expected Security Returns, Risk and Level of Interest Rates" Journal of Finance, (1989), 44, 1191-1217.

36. Fleming, M. J. and Remolona, E. M., "The term Structure of Announcement Effects," BIS working paper 71, (1999), Bank for International settlements.

37. Fleming, M. J. and Remolona, E. M., "What Moves the Bond Market?, Economic Policy Review - Federal Reserve Bank of New York, (1997), 3(4), 31-50.

38. Flennery M.J. and Protopapadakis, A., "Macroeconomic Factors do Influence Aggregate Stock Returns," Review of Financial Studies, (2002), 15 (3), 751 - 782.

39. Forbes, K.J. and Chinn, M., "A Decomposition of Global Linkages in Financial Markets over Time", Review of Economics and Statistics, (2004), 86(3), 705-722.

40. Forbes, K.J. and Rigobon, R., "No Contagion, Only Interdependence: Measuring Stock Market CoMovements." The Journal of Finance, (2002), 57 (5), 2223-2261.

41. Glick, Reuven and Andrew Rose, "Contagion and Trade: Why Are Currency Crises Regional?" Journal of International Money and Finance, (1999), 18, 603-617.

42. Goldberg, L. and Leonard, D., "What Moves Sovereign Bond Markets? The Effects of Economic News on U.S. and German Yields," Current Issues in Economics and Finance, Federal Reserve Bank of New York, (2003), 9, 1-7. 
43. Granger, C. W. J., "Developments in the Study of Co-integrated Economic Variables," Oxford Bulletin of Economics and Statistics, (1986) , 48(3), 213-28

44. Griffin, J.M. and Andrew Karolyi, G., "Another Look at the Role of the Industrial Structure of Markets for International Diversification Strategies." Journal of Financial Economics, (1998), 50, 351-373

45. Hamao, Y., Masulis, R.W. and Ng, V., "Correlations in Price Changes and Volatility across International Stock Markets," Review of Financial Studies, (1990), 3, 281-307.

46. Hartmann, P., Straetmans, S. and de Vries, C., "Asset Market Linkages in Crisis Periods", Review of Economics and Statistics, (2003). 86(1), 313-326.

47. Heston, Steven L. and Geert Rouwenhorst, K., "Does Industrial Structure Explain the Benefits of International Diversification?" The Journal of Finance, (1994), 36, 3-27.

48. Johansen, S., "Statistical Analysis of Co-integration Vectors," Journal of Economic Dynamics and Control, (1988), 12, 231-254.

49. Jonansen, S., "Estimation and Hypothesis Testing of Cxointegration Vectors in Guassian vector Autoregressive Models" Econometrica, (1991), 59, 1551-1580

50. Jorion Philippe and MIshikin Fredric, "A Multi Country Comparison of Term Structure Forecasts at Long Horizons" Journal of Financial Economics, (1991), 29 (1), 297-320.

51. King, M., Sentana, E.,Wadhwani, S., "Volatility and links between national stock markets", Econometrica, (1994), 62, 901-934.

52. Lieven Baele, Greet Bekaert and Koen Inghe lbrethcs, "The determinants of Stock and Bond Return co movements", Review of Finance Studies, (2010), 23(6), 2374 - 2428.

53. Lin, W., Engle, R.F., Ito, T., "Do bulls and bears move across borders? International transmission of stock returns and volatility", Review of Financial Studies, (1994), 7, 507-538.

54. Mishikin Fredric, "What does the Term Structure tell us about the Future Inflation" Journal of Monetary Economics, (1990), 25 (1) 77-95.

55. Ramesh Babu, T. and Venkateshwarlu M., "Dynamic Integration of Emerging Stock Market with World Stock Markets," International Economic and Finance Journal, (forth coming) Jan -June, 2011.

56. Rigobon, R. and Sack B., "The impact of monetary policy on asset price“" Journal of Monetary Economics, (2004), 51(8), $1553-1575$.

57. Rigobon, R. and Sack, B., "Measuring the reaction of Monitory Policy to the Stock Market," Quarterly Journal of Economics, (2003), 118, 639 - 70.

58. Schwert, G. W., "Stock Returns and Real Activity - A century of Evidence," Journal of Finance, (1990), 44 (5), 1115-53.

59. Shiller, R. J., Campbell J.Y. and Kermit L. S., "Forward Rates and Future Policy: Interpreting the Team Structure of Interest Rates." Brookings Papers on Economic Activity, (1983), 1, 173 - 217.

60. Shiller, R.J., "The Volatility of long-term Interest Rates and Expectations Models of the Team Structure." Federal Reserve Bank of Philadelphia Research Paper No. 36, (1978).

61. Shiller, R.J., and Beltratti, A.E., "Stock prices and bond yields: Can their co movements be explained in terms of present value models?," Journal of Monetary Economics, (1992), 30, 25 - 46.

62. Shiller, Robert J., "Co movements in Stock Prices and Co movements in Dividends," Journal of Finance, (1989), 44, $719-729$.

63. Shridhar Kumar Dash, "Efficiency of Indian Foreign Exchange Market", Journal of Foreign Exchange and International Finance, (2000), 12(1), 35-44. 
NOTES 